being so often the main source of pertinent expertise and hoped-for support, and apparently ignoring all of Australasia-Oceania.

The WCED Secretariat is led by Mr James MacNeill, who is responsible to the Chairman of the Commission and is himself an ex-officio member hailing from Canada. Financing of the World Commission is on the basis of voluntary contributions of funds or of services-in-kind from governments or other institutions and sources. Its accounts are subject to external audit. Japan, Sweden, Switzerland, Canada, Netherlands, Norway, Denmark, and Finland, were the first to pledge resources to WCED and their "contributions were sufficient to assure the Commission of the resources to start its work on a realistic scale'.

Establishment of WCED reflects a conviction that a future can be built which should be more prosperous or at least secure than the present-if only it can be made to depend on policies and practices that are both ecologically and economically sustainable. But what can such a Commission do that other agencies cannot? Among the advantages of the 'Commission approach' to such prospects we may cite the personal independence of its members, the stimulation of international processes of deliberation, and active mobilization of leading scientific and other specialists for guidance and advice with a focus on emerging or foreseeable challenges rather than on the short-term preoccupations of national governments.

The Commission aspires to draw on the best obtainable scientific and other advice for help in performing 'its principal task, namely: to re-examine the critical issues of environment and development and formulate new and concrete action proposals to deal with them; to assess and propose new forms of international cooperation that can break out of existing patterns and foster needed change; and to raise the level of understanding and commitment everywhere'. It intends to perform its work in as open and visible a manner as possible, holding meetings in many different parts of the world in order to "permit good regional access'; and 'it will call on the world's media both to popularize contributions received and the Commission's own work and, wherever practical, to provoke and gather new ideas and sound out public opinion'.

It is most ardently to be hoped that the Commission will take a firm stand on over-population, and also be effectively outspoken in dealing with military threats to the environment and to properly sustainable development.

In view of the close coincidence of many of our own efforts and hopes for the future, it is especially gratifying to welcome this large-scale operation alongside our primarily educational WCB-ISEE voluntary 'shoestring' ones which were featured widely in our last issue. The address of the World Commission on Environment and Development is: Palais Wilson, 52 rue des Paquis, 1201 Geneva, Switzerland-Tel. (022) 32.71.17; Telex $27910 \mathrm{csen} \mathrm{ch}$, where it is understood all serious contacts will be welcomed.

Nicholas POLUNIN

\title{
Our Change of Address: But Not of Office, Abode, or Telephones
}

Whereas the many from among our friends and collaborators who have graced our abode or visited our office since we moved in from the country more than a dozen years ago will, we sincerely hope, remember where we are usually to be found and will soon visit us again, we warn them that, although our abode and office remain the same, the name of the street on which we are situated, and also the number, have been changed by the authorities to 7 Chemin Taverney.

Our telephone numbers remain the same ([022] 982383 and 84 ) and so, we hope-with a benevolent 'assist' from
Father Time-do we. So for once (and for visitors and correspondents) I'll record our full address in these columns, hoping that any remaining confusion among would-be visitors and even dinner-guests will soon cease:

\author{
N. P. \\ THE FOUNDATION FOR ENVIRONMENTAL \\ CONSERVATION \\ 7 Chemin Taverney \\ 1218 Grand-Saconnex \\ Geneva, Switzerland.
}

\section{Threatened Plants and Animals of the World}

A nutritious nut that could help to save Ethiopia and Somalia from future famines, the world's smallest mammal, the largest butterfly, and the largest flower, have been chosen as representative of the world's most endangered species. They were among 12 plants and 12 animals identified as among the world's most endangered species by the International Union for Conservation of Nature and Natural Resources (IUCN) at its General Assembly in Madrid on 14 November 1984.

The Yeheb Nut-bush (Cordeauxia edulis) grows in the arid lands of the Horn of Africa. In 1929 it constituted up to half of the woody vegetation in many areas of Somalia, but it is now much reduced and its existence is threatened by drought, overgrazing by goats, and war, although the Somali National Range Agency has now set aside reserves. Heavy harvesting of seed and browsing by goats severely reduce the chances of natural regeneration, though great interest has been expressed in its potential as a source of food.
The Bumblebee Bat (Craseonycteris thonglongyai), the world's smallest mammal, only became known to science in 1974. It weighs only two grams and really is only as big as a large bumblebee. It lives in remote limestone caves in Thailand, and its existence could be threatened by museum and zoo collectors. Moreover, proposed hydroelectric projects menace this tiny Bat's cave habitat.

The Giant Rafflesia (Rafflesia arnoldii), a metre-wide parasitic flower, is threatened by destruction of the rainforest in Sumatra, while the world's largest butterfly is now severely threatened by expanding oil-palm and logging industries. It is Queen Alexandra's Birdwing (Ornithoptera alexandrae), of Papua New Guinea.

The representative threatened species were selected by scientists under the aegis of IUCN's Species Survival Commission, who declared that priority action was required to save them from extinction. Mr Grenville Lucas, Chairman of the Commission, declared: 'More than 1,000 vertebrate species are in danger of extinction, including many specta- 